\title{
Popular music
}




\section{Sounds of the railroad in boogie- 18 woogie, bluegrass, blues and jazz}

Several musicologists specializing in blues and jazz have written about the connection between train sounds and the development of American popular music in the twentieth century. ${ }^{1}$ This chapter looks further into these railroad sound connections in the evolution of different popular music styles, boogie-woogie, bluegrass, blues and jazz. The section on jazz focuses on some of the most well-known locomotive-inspired pieces for jazz bands, notably the big band sounds of Duke Ellington and Glenn Miller, moving on to the R\&B classic 'Choo choo ch'boogie' by Louis Jordan's band.

The chapter opens with instrumental pieces whose main intention is to replicate the sounds of the train. The favourite instruments for train imitation pieces are the harmonica and the fiddle. The harmonica, or blues harp as it is often known, lends itself to replicating train sounds because of the special effects that can be produced in various ways: cupping the hands over the instrument and opening and closing them to vary the sound; fluttering the fingers; and controlling the flow of the breath. It is also easy to 'bend' notes on the instrument. Note bends, a characteristic of blues and jazz, are where the pitch of a note is changed slightly, usually raised. Each of the following harmonica solos depicting the sounds of a train was recorded in the Southern States of America in the late 1920s. 


\section{0 train imitations with harmonica}

\begin{tabular}{|l|l|}
\hline SONG TITLE & ARTIST \\
\hline C \& O excursion & Frank Hutchinson \\
\hline C \& NW blues & Bert Hunter Bilbro \\
\hline Chickasaw Special & Noah Lewis \\
\hline Dixie Flyer blues & De Ford Bailey \\
\hline Double headed train & Henry Whitter \\
\hline Lost train blues & Henry Whitter \\
\hline McAbee's railroad piece & Palmer McAbee \\
\hline Pan American blues & De Ford Bailey \\
\hline Railroad blues & Freeman Stowers \\
\hline Riding the blinds & Eddie Mapp \\
\hline
\end{tabular}

The two pieces, 'Pan American blues' and 'Dixie Flyer blues', are both performed by the African-American De Ford Bailey who spent many years perfecting the sound of both the engine and the whistle. These impressions are alternated in 'Pan American blues' which imitates the sound of an express freight train. 'Dixie Flyer blues' also alternates the engine and whistle sounds, but it has a more bluesy feel and makes much use of note bends. ' $\mathrm{C}$ and NW blues' is performed by the one-time blackface comedian Bert Hunter Bilbro. ${ }^{2}$ It opens with an accelerating rhythm imitating the engine sound and then, with great instrumental skill, Bilbro introduces a train whistle sound and actually combines it with the sound of the engine. Palmer McAbee's rendition of 'McAbee's Railroad Piece' is an astonishing virtuoso harmonica solo. McAbee's imaginative interpretation of train sounds opens with the sound of steam escaping as he blows across the top of the instrument. The engine accelerates and when it gets to full speed he uses his throat to produce growling engine sounds.

The fiddle also lends itself to train imitations, this is partly because of doublestopping (where two notes can be played at once) and partly because it is a fretless instrument meaning that it is possible to slide from one note to the next. Most of the pieces listed below are played by string bands which were made up of acoustic stringed instruments - fiddles, five-string banjos, mandolins (occasionally) acoustic guitars and double bass. Apart from the recording of 'Orange Blossom Special', all of the listed pieces were recorded in the 1920s and 1930s when the popularity of the string band was at its height. They are all rooted in bluegrass music, a 
type of energetic folk music which originated in the American Appalachians and is noted for its rapid tempos and solo improvisations. Country music scholar Charles Wolfe has argued that bluegrass 'resembles the unique sound of the train: the clattering of the drivers echoed by the rolling banjo; the straight, true, hard steel rails resembling the empowering drive of the rhythm guitar; and the wail of the whistle calling up the long, edgy strokes of the low bow fiddle, ${ }^{3}$

\section{0 train imitations with fiddle}

\begin{tabular}{|l|l|}
\hline SONG TITLE & ARTIST(S) \\
\hline C \& NW railroad blues & Byron Parker's Mountaineers \\
\hline Donkey on the railroad track & Al Hopkins And His Hillbillies \\
\hline Engineer Frank Hawk & Rainey Old Time Band \\
\hline Lost train blues & Fred Perry (fiddle) Glenn Carver (guitar) \\
\hline New lost train blues & J E Mainer's Mountaineers \\
\hline Orange Blossom Special & American Music Shop Band with Mark O'Connor \\
\hline Peanut Special & Byron Parker's Mountaineers \\
\hline Southern No 111 & Roan Country Ramblers \\
\hline Train Special & Walter Hurdt and his Singing Cowboys \\
\hline Western Kentucky Limited & E E Hack String Band \\
\hline
\end{tabular}

From 1925 to 1953, the Orange Blossom Special was a deluxe passenger train on the Seaboard Airline Railroad connecting New York City and Miami. The song 'Orange Blossom Special' was written in 1938 by Ervin T Rouse. It has become best known as a show piece for the fiddle, a vehicle showcasing the player's virtuosity, often performed at breakneck speed. The recording by Mark O'Connor and the American Music Shop Band is particularly impressive, showcasing the pyrotechnic skills of both the fiddler and the harmonica player.

\section{Railroad sounds}

The Canadian composer and educator R Murray Schafer, who has written extensively on the soundscape of our environment, writes that in comparison with their modern counterparts, the sounds of steam trains were rich and characteristic. 
Of all the sounds of the Industrial Revolution, those of trains seem across time to have taken on the most attractive sentimental associations... the whistle, the bell, the slow chuffing of the engine at the start, accelerating suddenly as the wheels slipped, then slowing again, the sudden explosion of escaping steam, the squeaking of the wheels, the rattling of the coaches, the clatter of the tracks ... these were all memorable noises. ${ }^{4}$

Schafer goes on to write about the sound of train whistles. 'In North America... the whistle is low and powerful, the utterance of a big engine with a heavy load. On the prairies...the periodic whistlings resound like low haunting moans. ${ }^{5}$ Howard Bloomfield, one of Schafer's colleagues on his soundscape projects at Simon Fraser University, believed that the railroads influenced the development of jazz and that 'blue notes can be heard in the wail of the old steam whistles.' By 'blue notes' Schafer was referring to a musical characteristic of blues and jazz where some notes, are flattened by a semitone or 'bent' by a smaller interval. Blue notes are usually found on the third, fifth or seventh degree of the scale. Alan Lomax, arguing that the distinctive feeling of American hot music comes from the railroad', also makes reference to the characteristic sound of the whistle. He holds that 'it is the surge and thunder of the steam engine, the ripple of the wheels along the tracks, and the shrill minor-keyed whistles that have colored this new American folk music. ${ }^{7}$

In his analysis of the ways that the railroads have influenced American popular music, Lomax describes how the influence can be found in the music's texture. The word 'texture' refers to the simultaneously sounding lines in a piece of music, the number of layers, and the way that the rhythms bind together, for example.

It is in the textures of our popular music, however, that the railroads have left their deepest impression. Listen to the blues, the stomps, the hot music of the last fifty years, since most Americans have come to live within the sound of the railroad. Listen to this music and you'll hear all the smashing, rattling, syncopated rhythms and counter-rhythms of trains of every size and speed. Listen to boogie-woogie with its various kinds of rolling basses... What you hear back of the notes is the drive and thrust and moan of a locomotive. ${ }^{8}$ 


\section{Boogie-woogie}

Lomax makes specific reference to the counter rhythms and the rolling basses of boogie-woogie music. Boogie-woogie is a piano style which was most popular during the 1920s and 1930s but has had a major influence on different rock and blues styles. It is thought to have originated in Texas but became popular in Chicago and Detroit where boogie-woogie pianists provided the music for dancing at 'rent parties' during the years of the Depression. Rent parties were thrown in urban black communities; an entrance fee was charged to pay for food, drink and entertainment and the money was collected to pay the rent. The piano was the only instrument playing so it had to be loud, partly to attract passing custom. The front was taken off and newspaper was put between the strings.?

The essence of the boogie-woogie piano style is the contrast between the left and right hands. The left hand plays an ever-recurring driving bass line, sometimes known as a 'walking bass' or a 'rolling bass', keeping the beat and providing the chords. The chords usually followed the twelve-bar blues pattern. At the same time the right hand provides an embellished melody often set up in cross rhythms, what Lomax refers to as counter-rhythms, against the left hand. Here are some examples of the rolling basses of the left hand bass part.

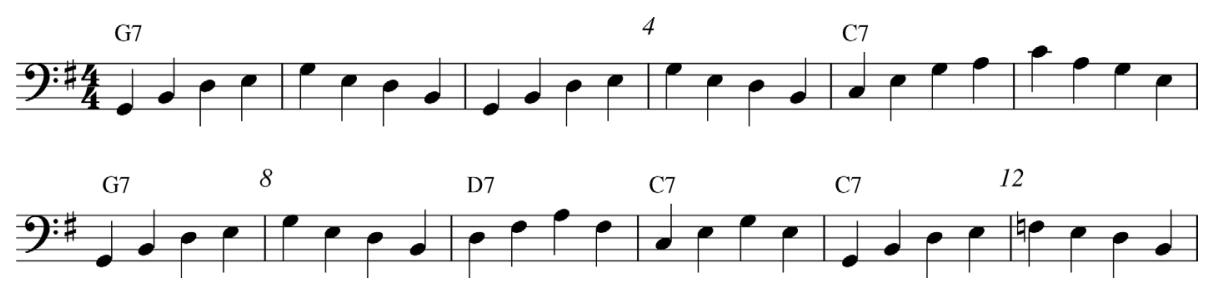

Notice how the note pattern of each bar is repeated, but shifted up or down to the next chord. Boogie-woogie bass lines often use quavers (eighth notes) as in the following example.

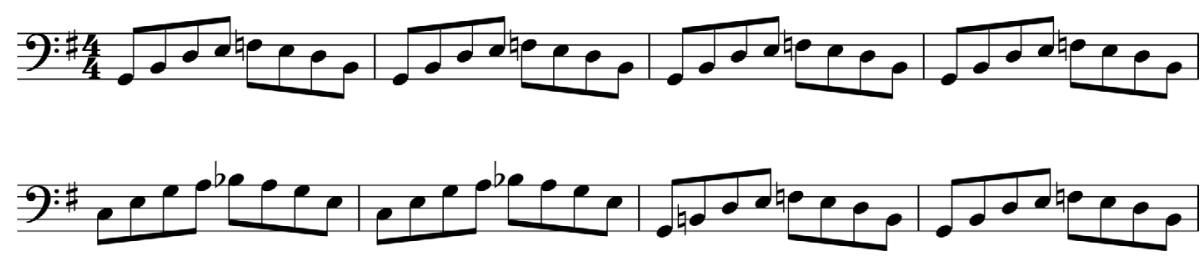


Sometimes chords are used providing a useful musical imitation of an engine moving along the tracks.

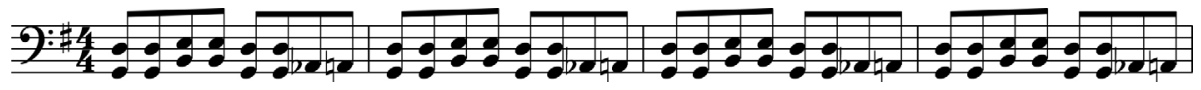

These are played in a swung rhythm where, in each pair of notes, the first note is performed a little longer than the second and with a little more emphasis.

\section{Honky tonk train blues by Meade Lux Lewis}

The boogie-woogie piano piece 'Honky tonk train blues' was first recorded in 1927 and soon became very popular. The chugging engine rhythm can be heard in the right hand. These bars, taken from near the opening, show the polyrhythmic interplay between the left and right hand. The left hand notes come in pairs, whereas those of the right are often in threes - triplets. Boogie-woogie pieces are often technically demanding, mainly because of the rhythmic independence required between the player's hands where twos are set against threes.
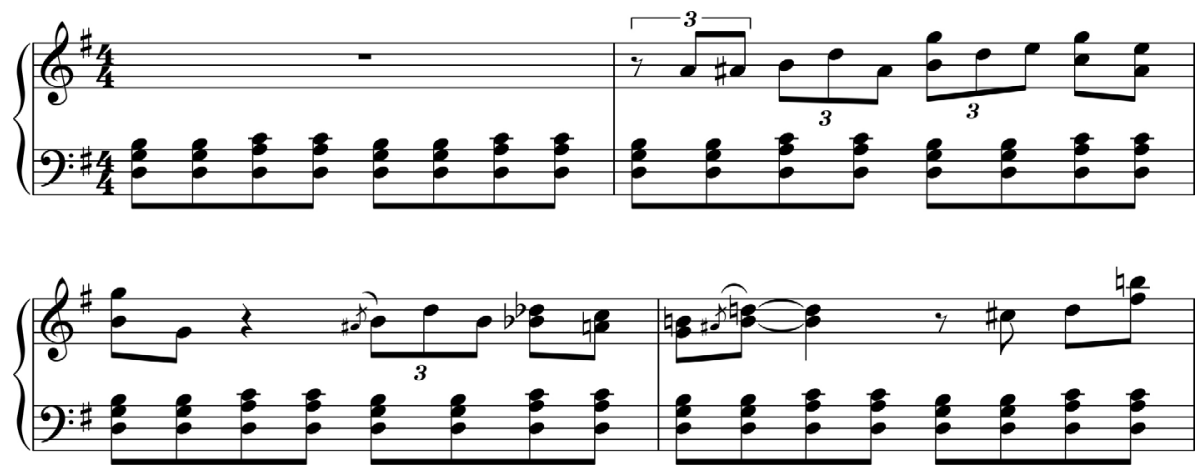

In the next section Lewis uses another common device found in the boogiewoogie style where the right hand uses riffs (short repeated figures).

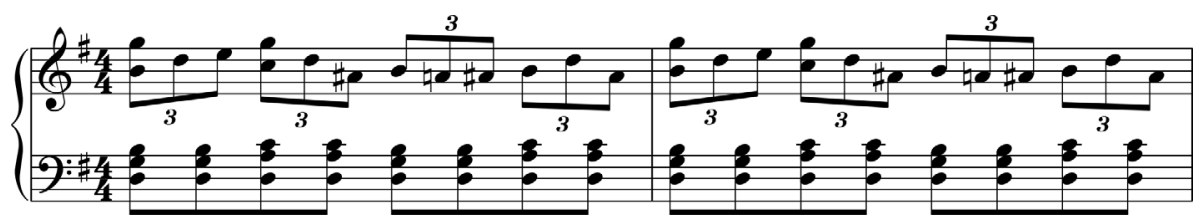


No. 29 by Wesley Wallace

This boogie-woogie piece by Wesley Wallace is about the No. 29 train. It is unusual in two ways. In the same way as most popular songs, the very large majority of boogie-woogie pieces have four beats to the bar, whereas 'No. 29' has three beats in a bar. Secondly, Wallace makes a running commentary about his train journey throughout and illustrates this with train sound effects on the piano. The performance is a tour de force. The left hand has running quavers throughout depicting the train's motion, whilst the intricate melodic right hand is interspersed by train imitations. Wallace's running commentary is as follows.

This is the train they call 29. Leavin' out of Cairo, comin' to East St. Louis. Soon as she got in Murphysburg, she blowed that whistle. She blowed her whistle this way: (piano imitates whistle with repeated chords in its high register).

She blow the whistle this way
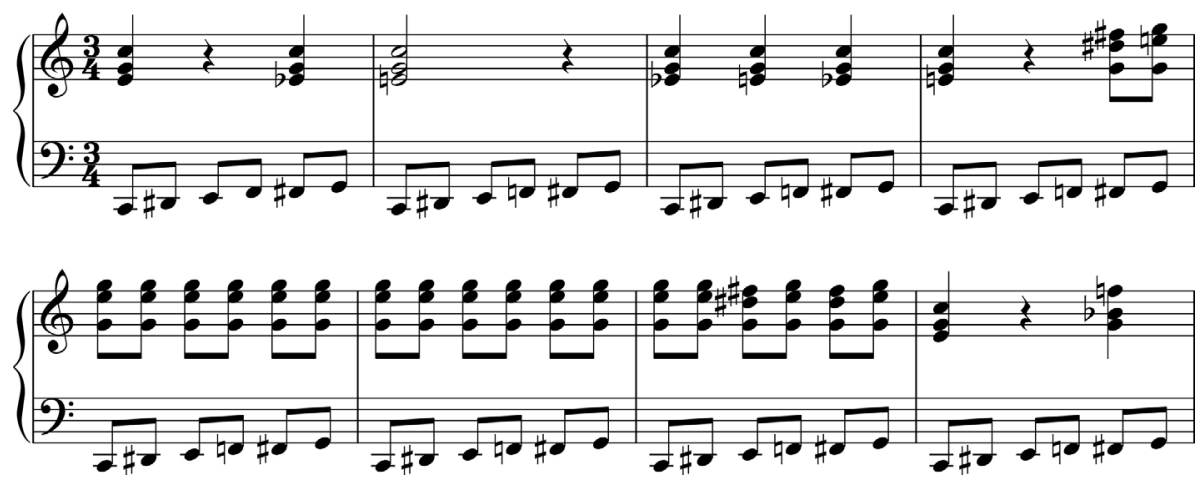

I caught that train in Murphysburg. I was intendin' to get off in Sparta, Illinois. I mean, that train was runnin'!

She wasn't doin' nothin' but runnin', hot, a' somethin' like this: (piano imitates train runnin'). 
I mean that train was runnin'. She wasn't doing nothin' but runnin' hot, something like this
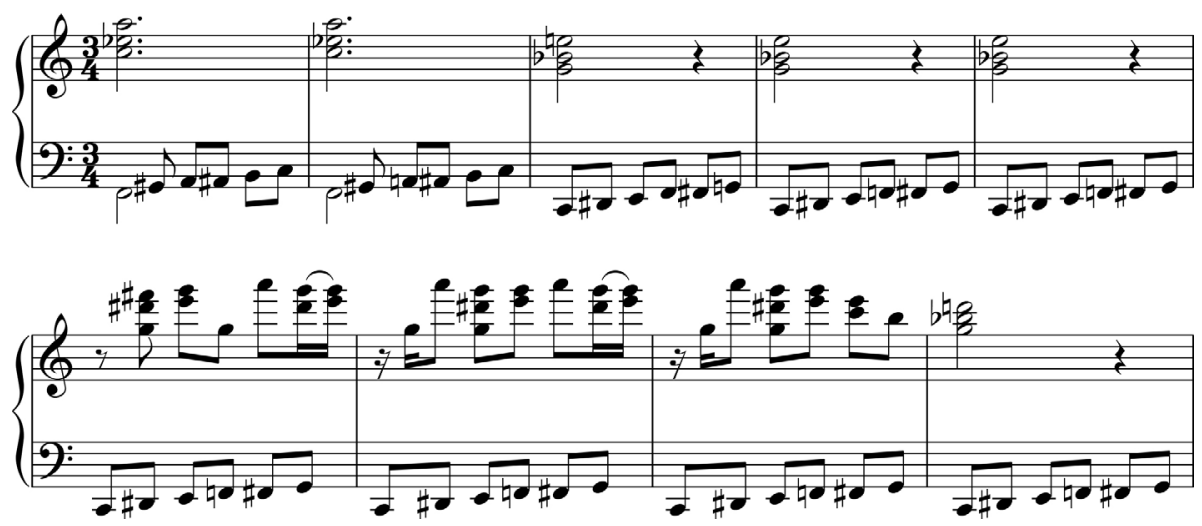

Just before she got to Sparta, she thought she'd blow that whistle again. She blowed that whistle somethin' like this: (piano imitates whistle).

She's lopin' now. I wanted to get off that train, but she's goin' too fast. I hardly ain't touched one foot on the ground, my beel like to knock my brains out. I always step four or five, right tight ... and fell off.

This is the noise I made when I bit that ground: (piano imitates impact with clattering chords).

I'm rollin' now. I got up and waved my hand, told 'em, "Good-bye."

This is the way she was cakewalkin' on into East St. Louis: (piano plays in the cakewalk dance style).

Wesley Wallace is not the only musician to set a narrative to music depicting a train. Here are some more examples.

\section{Train songs with spoken narratives}

\begin{tabular}{|l|l|}
\hline Song & Artist \\
\hline Travelling blues & Blind Willie McTell \\
\hline The train & Furry Lewis and Will Shade \\
\hline Talking Casey blues & Mississippi John Hurt \\
\hline Streamline 'Frisco Limited & Rev. Robert Wilkins \\
\hline Special streamline & Booker White \\
\hline Ragtime Texas & Henry Thomas \\
\hline Panama Limited & Booker White \\
\hline Going North & Tom Bradford \\
\hline Frisco leaving Birmingham & George 'Bullet' Williams \\
\hline Big boy blues & Leon Strickland \\
\hline
\end{tabular}




\section{Jazz}

\section{Duke Ellington and locomotive music}

Edward 'Duke' Ellington (1899-1974) was an American pianist, composer and bandleader. He came from a well to do family in Washington DC (his father was a butler at The Whitehouse) and moved to New York in the early 1920s playing at the fashionable Cotton Club in Harlem. This was at the time when big bands were becoming popular and Ellington helped to develop the big band jazz style. His band was made up of three sections - saxophones, brass (trumpets and trombones), and a rhythm section - each playing off each other in a call-andresponse style. He wrote hundreds of compositions for them, discovering new tone colours and textures and always writing to the strengths of individual musicians. As well as writing successful popular songs he also composed sophisticated jazz music. Soon his band, with him at the piano, was making tours of the US and then later, worldwide. He continued to lead bands until his death in 1974.

Ellington loved trains and he spent long hours on them travelling on tour. At times he even rented his own train car in order that he and his band members would have a place to eat and sleep when they were touring in segregated towns. The train was his sanctuary. His sister Ruth once told his biographer Derek Jewell that 'You'd see him in a siding somewhere in Texas, the heat at 110, the sweat pouring off him on to a piece of manuscript paper on his knee'. Jewell writes

He would listen to the chattering of trains at crossings, to the hissing and chuffing as they left stations, and above all the whistles. 'Especially in the South. There the firemen play blues on the engine whistle - big, smeary things like a goddam woman singing in the night ${ }^{10}$

He often composed while riding on trains and wrote a whole series of pieces evoking the joys, and often imitating the sounds, of train travel. His locomotiveinspired songs include 'Daybreak Express' 'Happy go lucky local' and 'The old circus train turn-around blues'. His signature tune, 'Take the A train', however was written by Billy Strayhorn. In Stompin' the Blues, Albert Murray argues that, although train sounds were integral to such songs, Ellington's compositional approach was in terms of form and craft rather than 'railroad 
mimicry'. Murray writes 'although the railroad sounds in such Ellington compositions...remain unmistakable...even the most literal imitation of the sound of the most familiar everyday phenomenon becomes an element of musical stylization and convention... what all the whistles, steam-driven pistons, bells, and echoes add up to is the long-since-traditional sound of bluesidiom dance-hall music."11 This point is reinforced by Jewell when he writes that the 'feeling for trains is obvious; but what Duke added to the mixture of train-like sounds and rhythms provided the magic.'. ${ }^{12}$

\section{0 train pieces by Duke Ellington}

\begin{tabular}{|l|}
\hline Take the A Train \\
\hline Daybreak Express \\
\hline Across the track blues \\
\hline Lightnin' \\
\hline The old circus train turn-around blues \\
\hline Choo choo (gotta hurry home) \\
\hline Build that railroad (sing that song) \\
\hline Loco Madi \\
\hline Happy go lucky local \\
\hline Track 360 aka Trains that pass in the night \\
\hline
\end{tabular}

\section{'Daybreak Express'}

Barney Bigard, a clarinettist in Ellington's band once said in interview

You know the record, 'Daybreak Express'? Well, when we were in the South, we'd travel by train in two Pullmans and a baggage car. Duke would lie there resting, and listening to the trains. Those southern engineers could pull a whistle like nobody's business. He would hear how the train clatter over the crossing, and he'd get up and listen to the engine. He'd listen as it pulled out of a station, huffing and puffing, and he'd start building from there... He had the whistles down perfectly, too. ${ }^{13}$

'Daybreak Express' (1933) is built on the chords of 'Tiger Rag', an earlier Ellington song. It portrays a steam engine leaving the station, accelerating to 
top speed, blowing its whistle and then coming to a halt. It provides one of the most vivid pictures of a speeding train in music. With its noisy, powerful, chords, rolling ostinati, complete with wailing whistle and clanging bell, it has a sense of the immediate urgency of a pounding express. The piece abounds with bends and slides on the saxophones and wah-wah trumpets. In 2013 the Los Angeles Times maintained that 'Daybreak Express' was rarely performed 'because no one has figured out precisely how he got his reeds to replicate the sounds of a steam whistle. ${ }^{.14}$

\section{'Happy go lucky local'}

In his autobiography, Ellington wrote that 'Happy go lucky local'

told the story of a train in the South, not one of those luxurious, streamlined trains that take tourists to Miami, but a little train with an upright engine that was never fast, never on schedule, and never made stops at any place you ever heard about. After grunting, groaning, and jerking, it finally settled down to a steady medium tempo. ${ }^{15}$

The big band composition opens with rumbles, groans, shrieks, squeaks and dissonance, one repeated pattern (ostinato) after another, all set over a steady beat. There is no clearly identifiable melody until well into the piece. In the early bars we hear piano and bass as the train starts to move. Reeds and brass enter with saxophone solos and long, screaming notes on plunger muted trumpet, reminiscent of the whistle of a passing train, all accompanied by the trombones, sounding like the chugging of the train's engine.

\section{'Take the A train'}

'Take the A Train' is a jazz standard, composed in 1939 by Billy Strayhorn. Ellington was in the middle of a negotiating stalemate with the licensing agency American Society of Composers, Authors and Publishers (ASCAP); all music by ASCAP members-including Ellington himself-was barred from the airwaves. Ellington needed a new library of songs by a non-agency member, and turned to his young friend - the arranger and collaborator, Billy Strayhorn. Its 
opening theme is unusual in its use of wide leaps, but it is also very hummable. Ellington soon adopted it as his signature tune. The lyrics are about choosing the then-new A train to get to Harlem in preference to the D train. Apparently a common mistake was to take the ' $\mathrm{D}$ ' train and end up in the Bronx. The story goes that the title evolved from the directions that Ellington gave Strayhorn on how to get to his Harlem apartment by subway. Ellington lived in the elegant African-American of Sugar Hill located between 144th and 155th Street. As Strayhorn once said, he was writing subway directions. ${ }^{16}$

You must take the A train

To go to Sugar Hill way up in Harlem

If you miss the A train

You'll find you've missed the quickest way to Harlem

Hurry, get on, now it's comin'

Listen to those rails a-hummin'

All aboard get on the A train

To go to Sugar Hill way up in Harlem.

The song is in the 32-bar AABA form which was popular with swing and jazz bands of the time. It opens with solo piano playing the same bar of downward flourishes four times. The locomotive is suggested in the constant movement and rolling ostinato of the rhythmic brass and reed accompaniment. The joyful main theme is first played by saxes in unison, punctuated by the other horns. A muted-trumpet solo backed by the reeds leads to another stirring riff by the full band. A long trumpet solo follows, first muted and then open. The song changes key by means of blasts from the full band in the passage between the muted and open trumpet. Loud dissonant chords from the band towards the end of the solo are suggestive of a train's warning signal.

Ellington and the band performed the song in the film Reveille with Beverly (1943) with the singer Betty Roche. The band is shown performing in a railroad passenger car rather than a subway car. The song was an instant hit and since Ellington's recording there have been many others including those by Ella Fitzgerald, Joe Henderson, Charlie Mingus, Sun Ra, and the rock band Chicago. 


\section{The Glenn Miller Orchestra}

Glenn Miller (1904-1944) was a bandleader, trombonist, composer and arranger. His band had a more commercial sound than Duke Ellington's. In his search for a unique sound he doubled he clarinet and tenor saxophone, whilst three other saxophones played in close harmony. He was the best-selling recording artist from 1939 to 1942 with 16 number-one records and 69 Top Ten hits. In 1942, he volunteered to join the US military to entertain World War II troops. He joined the US Army Air Forces, directing the American Air Force band and contributing a good deal to morale during the war. On December 15, 1944, when France had been newly liberated, Miller's Parisbound plane disappeared in bad weather over the English Channel. Neither the plane nor its occupants were ever found.

'Chattanooga Choo Choo' was written by Harry Warren and Mack Gordon for the band to perform in the film Sun Valley Serenade (1941). It was arranged for the Glenn Miller Orchestra by Jerry Gray. The band were incorporated into the story line, the lyrics describe the train's route, starting from Pennsylvania Station in New York and running through Baltimore to Carolina before reaching Chattanooga. A past love will be waiting at the station and he plans to settle down for good with her. At the time soldiers abroad were facing death, the song reminded them of the excitement of coming home. The main song includes a passage of dialogue.

\footnotetext{
"Pardon me, boy, is that the Chattanooga Choo Choo?"

"Yes, yes, Track 29!"

"Boy, you can give me a shine."

"Can you afford to board the Chattanooga Choo Choo?"

"I've got my fare, and just a trifle to spare."
}

The train station in Chattanooga, Terminal Station opened in 1908 and was a major transportation hub in the 1930s and 1940s. Gordon and Warren were reputed to have written the song while traveling on the Southern Railway's Birmingham Special train - one of three trains operating from New York City via Chattanooga. However some of the details in the song don't apply to the Birmingham Special, suggesting a certain amount of artistic licence on the part of the team. The song mentions 'Track 29' but New York's Pennsylvania Station only had 21 tracks. The Birmingham Special left at 12. 
30 rather than 'bout a quarter to four'. Although 'nothing could be finer' than to eat 'dinner in the diner' it would be difficult to do this since none of the trains between New York City via Chattanooga passed through Carolina. Chattanooga's former Terminal Station was saved from demolition after the withdrawal of the passenger rail service in the early 1970s. It is now part of a large resort complex and Chattanooga is home to the National Model Railroad Association.

That year it won an Academy Award for Best Song from a movie, even though it could not be heard on network radio due to the ASCAP boycott, the same boycott which had brought about the composition of 'Take the A Train'. Once the ASCAP strike was over it was featured heavily on radios across the country and in 1942 it went on to receive the first Gold Record for selling over a million copies. Other railroad pieces performed by the Glenn Miller Orchestra were 'Tuxedo Junction', Sleepy Town train,', 'Slow freight' and the Count Basie song '9.20 Special'.

\section{0 choo choo songs}

\begin{tabular}{|l|l|}
\hline SONG TITLE & ARTISTS \\
\hline Boogie-woogie choo choo train & Mabel Scott 1948 R\&B \\
\hline Bye bye black smoke choo choo & $\begin{array}{l}\text { Recordings by bluegrass artists Joe Glazer, The } \\
\text { New Lost City Ramblers, and Arthur Smith and } \\
\text { his Crackerjacks (1955) }\end{array}$ \\
\hline Chattanooga choo choo & Glenn Miller and his Orchestra 1941 Big band \\
\hline Choo choo & Frankie Trumbauer 1930 Big band \\
\hline Choo choo & Jack Hylton 1931 Big band \\
\hline Choo choo & Fats Waller 1939 Piano \\
\hline Choo choo (gotta hurry home) & Duke Ellington 1924 Jazz band \\
\hline Choo choo blues & Virginians 1922 Blues band \\
\hline Choo choo ch'boogie & Louis Jordan 1946 R\&B \\
\hline $\begin{array}{l}\text { When the midnight choo-choo } \\
\text { leaves for Alabam' }\end{array}$ & $\begin{array}{l}\text { Written by Irving Berlin in 1912. Recordings } \\
\text { include Judy Garland, Ethel Merman and Tommy } \\
\text { Dorsey }\end{array}$ \\
\hline
\end{tabular}




\section{'Choo choo ch'boogie' by Louis Jordan \& His Tympany Five}

Louis Jordan (1908 -1975) was an American saxophonist, bandleader and songwriter whose music was so popular that he was sometimes referred to as the King of the Jukebox. Born in Arkansas, Jordan left home in his teens and eventually moved to New York and formed the Tympany Five, an R\&B dance band made up of a horn section along with drums, double bass, guitar and piano - a sort of scaled down big band. R\&B (or rhythm and blues) was a blues style made for entertainment and dancing. Jordan teamed up with Milt Gabler, Decca's producer of 'race' records to produce a series of hits and he became the first black artist whose records crossed over to the pop charts.

The song was co-written by Milt Gabler and two country and western musicians who worked at a radio station in New York City. Like many of Jordan's songs 'Choo choo ch'boogie' is in the jump blues style, a sort of swingoriented happy version of the blues with a boogie-woogie beat. The verses follow the 12-bar blues structure and the choruses have eight bars. It has rapidfire witty lyrics and a hard-driving energetic sound. The record was released in 1946 and was soon a massive hit selling over two million copies. Part of its appeal is the way that the lyrics encapsulated the feelings of excitement, coupled with disillusionment, which many must have felt on returning from service in World War II; 'The only job that's open needs a man with a knack'.

The song opens with a 12-bar instrumental introduction in which the horns (two saxophones and a trumpet) imitate the sound of a train whistle. The rhythm section sets up a boogie-woogie shuffle and the vocals are joined by riffing horns, a boogie-woogie piano solo and a 20-bar saxophone solo. The rapidly fired vocals have their emphasis on the rhythm and some, including those of the catchy chorus, are onomatopoeic - 'whoo, whoo', 'choo, choo' suggesting the sounds of a train.

The success of the song inspired a number of the first rock ' $n$ ' roll artists including Bill Haley and his Comets. 


\section{Endnotes}

1 These include the blues expert, Paul Oliver, American folklorist, Alan Lomax, country music expert Charles Wolfe, and the American jazz and blues critic, Albert Murray.

2 White performers blackened their face with cork for the performance of black caricatures in minstrel shows.

3 Taken from the sleeve notes to the album Bluegrass Express, a compilation of train themed bluegrass songs.

4 R Murray Schafer. The soundscape. Our sonic environment and the tuning of the world. (Rochester, Vermont: Destiny Books, 1977): 81.

5 Schafer, The soundscape, 82.

6 Schafer, The soundscape, 113.

7 Alan Lomax, ed. Folk Song: USA, 1947.

8 Ibid.

9 Eileen Southern. The Music of Black Americans. A History. (New York: Norton, 1971): 372.

10 Derek Jewell. A Portrait of Duke Ellington. (London: Sphere Books, 1977): 79.

11 Albert Murray. Stomping the Blues. (Minneapolis: University of Minnesota Press, 1976): 125.

12 Jewell, A Portrait of Duke Ellington, 79.

13 James Lincoln Collier. Duke Ellington. (Oxford: Oxford University Press, 1987): 162.

14 Los Angeles Times, May 10, 2013.

15 Edward Kennedy Ellington. Music is my mistress. (New York: Doubleday. 1974): 162.

16 Jewell, A Portrait of Duke Ellington, 89. 